\title{
Adorno and Marx's Tradition of Critical Philosophy of History ${ }^{i}$
}

\author{
He Ping ${ }^{\text {ii }}$ \\ School of Philosophy, Wuhan University, China
}

Copyright $@ 2019$ by authors, all rights reserved. Authors agree that this article remains permanently open access under the terms of the Creative Commons Attribution License 4.0 International License

\begin{abstract}
Adorno's philosophy inherited and developed Marx's critical philosophy of history from the perspective of philosophy of history. Marx advanced the two principles in his philosophy of history: one is the criticism of capital or reason, the other the criticism of morality or culture. Adorn took the two principles to research into the cultural industry in late capitalism and rethink Auschwitz, while he criticized Enlightenment reason and developed Marx's concept of the critical philosophy of history at the microcosmic level of human nature. In the critique of the cultural industry, Adorno first pointed out the essence of the capitalization of the cultural industry. He emphasized that the so-called cultural industry is to turn culture into industrial production and become a sector in the economy, subjecting it to the need for capital accumulation. Therefore, economic benefit, that is, maximizing the acquisition of currency, becomes the inherent power and direct purpose of cultural development, which will inevitably lead to a complete alienation of culture from content to form. Furthermore, he reflected the spirit of enlightenment, emphasizing that the essence of the enlightening spirit was deceit and lies, and it was through deception and lies that the cultural industry stepped out of its place of production and had an impact on people's leisure, entertainment, consumption, and the entire way of life. In the reflection on Auschwitz, Adorno presents a profound philosophical question: 'Can on live after Auschwitz?' This issue is a search for the value of human life, and is also a condemnation of the barbaric practices of imperialism, even more a reflection on the history of human civilization. Adorno uses the principles of moral criticism of Marx's critical historical philosophy, criticizes the enlightenment spirit with a mode of civilized and barbaric dialectics, and pointed out that the deceptive elements of the spirit of enlightenment was the cultural roots of imperialist barbarism, in which he developed Marx's critical historical philosophy on the micro level in studying this issue. On this basis, he constructed the metaphysics of culture taking the concept of negation as core and presented the character of criticism of culture in Marx’s critical philosophy of history.
\end{abstract}

Keywords Marx, Adorno, Critical Philosophy of History, Cultural Industry, Negative Dialectics, Enlightenment Dialectics

\section{An Issue Worth Revisiting}

Is Adorno's philosophy Marxist or post-Marxist or postmodern? This is the most controversial debate and has never been solved in Adorno's philosophical study. People raised this issue and started to argue about it not only for the purpose of accurately positioning Adorno's philosophy, but also for answering many questions in the Marxist philosophy tradition and its development. Therefore, it is necessary and meaningful to choose a new perspective to revisiting the issue.

In the existing studies, the majority of scholars comment on Adorno in the context of Western and their conclusion is: Adorno's philosophy is the end of Western Marxist philosophy and the beginning of post-Marxism and post-modernism, [43] therefore, it is inevitably caught up in the post-modernist concept of "temporary, fragmented, and self-depleted conceptual gameplay" ${ }^{1}$ [22]. Fredrick Jameson challenged this conclusion and considered these conclusions to be overly superficial. In fact, no matter whether it is from the premise of philosophical research or from the question of philosophical research, Adorno did not make his philosophy fall into the post-modern situation, but he always stood on the Marxist standpoint, even adopting quite old-style Marxism position. From the philosophical premise, Adorno always bases his own interpretation on Marx's law of value, "or at least the evolution of capitalism and its development and some general Marxist meaning of the law of historical trends." ${ }^{2}$ [22] This is evident in his most important book,

1 Fredric Jameson. Late Marxism: Adorno, or, the persistence of the dialectic, Nanjing University Press, 2008, pp.28.

2 Fredric Jameson. Late Marxism: Adorno, or, the persistence of the 
Negative Dialectics, [14] [16] and the book written together with Horchheimer Enlightenment Dialectics.[20] In Negative Dialectics, Adorno's arguments for identity and non-identity follow the sameness thinking in the first piece of the first part of the first volume of Marx's Das Kapital. The concepts of use value and exchange value, currency abstraction, labor force, and productivity are the "key clues" 3 [22] of Adorno's philosophy; in Enlightenment Dialectics, "the law of value is obviously" only one of the many principles of social integration with the aid of instrumental rationality. ${ }^{4}$ [22] From the perspective of philosophical research, Adorno's exposition of the cultural industry is "concerns entertainment business, not a cultural range theory that he will never accept first" ${ }^{5}$ [22]. These are enough to prove that Adorno is a Marxist philosopher and his Marxist viewpoint is "more Marxist than traditional Marxism." ${ }^{6}$ [22] For the defense of Jameson, people may ask various questions, but one thing is beyond doubt. That is, Jameson has changed the context of the previous study of Adorno's philosophy. Again in the context of Western Marxism, but from the context of Marxist philosophy, specifically, using Marx's laws of value as a method to explain Adorno's philosophy and evaluate its nature and status. This opened up another academic direction for Adorno’s philosophy.

This raises a question: To show that Adorno is a Marxist, why not adopt the context of Western Marxism, but must adopt the Marxist context? The related question is: Is it reasonable to define Adorno as a Marxist? What is the basis for this definition? I think that to answer these two questions, we must first understand the uniqueness of Adorno's philosophy.

The uniqueness of Adorno's philosophy is reflected in two aspects: one aspect comes from the difference with Gramsci, [45] Kirsch and Lukács's[46] philosophy; the other comes from the difference with Marcuse's philosophy. In these two aspects, the former embodies the general characteristics of the Frankfurt school's critical theory, [32] [33] [34] [35] and the latter embodies the characteristics of Adorno's philosophy itself. [8] [9] [10] [24] [27] [28] [29] [30] [31] The critical theory of the Frankfurt School and the philosophy of Gramsci, Kirsch and Lukács were all formed in the 1920s-30s, were all developed from Marx's practical philosophical tradition and they went toward critiques of superstructures from the discussion of relationship between theory and practice. [13] [21] However, they both differ in the goals of the study, the task of theoretical construction, and theoretical forms and

dialectic, Nanjing University Press, 2008, pp.256.

3 Fredric Jameson. Late Marxism: Adorno, or, the persistence of the dialectic, Nanjing University Press, 2008, pp.24.

4 Fredric Jameson. Late Marxism: Adorno, or, the persistence of the dialectic, Nanjing University Press, 2008, pp.256.

5 Fredric Jameson. Late Marxism: Adorno, or, the persistence of the dialectic, Nanjing University Press, 2008, pp.256.

6 Fredric Jameson. Late Marxism: Adorno, or, the persistence of the dialectic, Nanjing University Press, 2008, pp.257. functions of the construction. The goals of Gramsci, Kirsch and Lukács' research are to solve the tactical problems of the proletarian revolution in the West. To achieve this goal, they reconstruct Marxism's practical ontology as an academic approach, creating cultural leadership and the ideological theory of the proletariat, which endows their theory with an intensive class character of the proletariat and it is the ideological weapon of the proletarian revolution in the West. While the majority of Scholars of the Frankfurt School sticked to the position of non-partisanship, in philosophy, they did not advocate the study of the Marxist ontology, but tried to rebuild the critical theory of Marxism on the basis of the critique of political economy in order to carry out a critique of the capitalist system and explore the economic problems of the Soviet Union. Adorno's philosophy is a classic of the Frankfurt School's critical theory, which determines that his theory is necessarily different from the theory of Gramsci, Kirsch and Lukács. [45] [46] Inside the Frankfurt school, Adorno's critical theory is different from Marcuse's critical theory. Marcuse is the most radical philosopher of the Frankfurt School. In theory, he was the first person to interpret Marx's Economic and Philosophical Manuscripts of 1844 and expounded Marx's humanitarian thoughts from the perspective of existentialism. [37] [38] [41] [47] He who accepted Kirsch and Lukács's Western Marxist philosophy, is an influential Hegelian Marxist philosopher. In practice, he had participated in the German Social Democratic Party in the early days and later because of protesting against the participation of the German Social Democratic Party in the assassination of Li Bulknessi and Rosa Luxemburg he withdrew from it. Owing to the theoretical and practical radical position, Marcuse regards the revolution and the liberation of man as the central concern of all his theoretical creations and practical activities, which make his theory transcend the theoretical framework of the Frankfurt school in vindicating the rationality of the revolution and the prospect of cultural criticism. Therefore, it is closer to the western Marxist theories of Gramsci, Kirsch and Lukács. In contrast, Adorno moves towards pessimism on account of the Frankfurt school's non-partisan stance.

For this dual uniqueness of Adorno's philosophy, the researchers can use it as a unique case of Western Marxism to be studied, which is the researchers' original intention as well. However, as these researchers adopted Kirsch's Western Marxist definition, and use the philosophy of Gramsci, Kirsch, and Lukács as the context to evaluate Adorno's philosophy. Therefore, they could not find the basis for attributed Adorno's philosophy to Western Marxism, and they could only attribute it to post-Marxism or post-modernism. Under these circumstances, if Jameson intended to change the explanation of Adorno's critical theory given by former researchers and prove that Adorno is a Marxist. He can only jump out of the context of Western Marxism and move towards a broader context of 
Marxism, discovering another philosophical tradition of Western Marxism by examining the relationship between Adorno and Marxist philosophies, thus proving that Adorno's philosophy and Gramsci and Kirsch and Lukács' philosophy is one source and multiple streams. Here, Jameson did put forward a meaningful topic in the study of Adorno's philosophy.

Unfortunately, Jameson did not complete his own project, because he limited the investigation of the relationship between Adorno and Marxism to the level of political economy criticism, and commented on it in the theoretical framework of traditional historical materialism. This has led his research to be superficial and fragmented, but it cannot reveal the intrinsic link between Adorno's and Marx's philosophical traditions, and shows how Adorno's philosophy emerged from Marx's philosophy. In order to overcome the narrowness of Jameson's perspective, this article attempts to examine the relationship between Adorno and Marxist philosophy from the perspective of historical philosophy, in order to clarify the nature of Adorno's philosophy and its contemporary inspiration.

\section{The Social Prototype of Historical Criticism}

When the Frankfurt School was founded, Horkheimer explicitly proposed that the ultimate goal of social philosophy is to "make a philosophical explanation of the rise and fall of human destiny." 7 To achieve this goal, the Frankfurt School must abandon Descartes's natural science approach, while follow the theoretical path of Marx's criticism of political economy and establish a new concept of historical philosophy. In this way, he attributed the critical theory of the Frankfurt School to the tradition of historical philosophy, and it is Marx's Tradition of Critical Historical Philosophy. Horkheimer's philosophical orientation of critical theory provides us with theoretical basis for examining the relationship between Adorno's and Marx's critical historical philosophy from the perspective of historical philosophy. Defining Marx's philosophy of history as a critical historical philosophy is relative to the previous philosophy of history which explores the origins of human civilization by examining the ancient Greek national languages, customs, and institutions, and other cultural forms based on the social prototype of the Greek national society in the Homeric era. Therefore, it is called Textual philosophy of history. Vico is one of the founders of the historical philosophy. His New Science [44]is a model of historical philosophy. When Marx founded the historical materialism, he inherited the tradition of Vico's

7 Max Horkheimer: The Present Situation of Social Philosophy and the Tasks of an Institute for Social Research, Max Horkheimer: Between Philosophy and Social Science, selected Early Writings, The MIT Press, Cambridge, Massachusetts, Cambridge, Massachusetts, 1993, p.1. philosophy of history ${ }^{8}$ [44] He used Britain as the typical form of capitalist society and dissected the English "capitalist mode of production and the production relations and exchange relations with it" ${ }^{9}$ [1]. The formation and development of modern society reveals the laws of human history. We are aware that the nature of capitalist societies and Greek national societies in the era of Homer is completely different: Greek national societies in the era of Homer are primitive societies whose social foundation is the natural economy, and its main forms of culture are myths and the original religion. So it shows people an irrational, imaginary world, while capitalist society is a modern society whose social foundation is industrial civilization. Its main form of culture is science, economics, politics, language, and art, ect, which adapt to it. Therefore, it shows people a rational, scientific world. Due to the different social prototypes of the study, Marx changed the research direction of previous historical philosophy. That is, he did not adopt a positivist research method, but adopted a critical and negative research, thus turning historical philosophy from the textual philosophy of history to critical philosophy of history.

In the anatomy of capitalist society, Marx put forward two critical principles: one is the principle of capital criticism, or the principle of rational criticism.[2] This principle emphasizes that the movement of capital is the entire foundation of capitalist society and determines the economic, political, cultural and ideological aspects of capitalism. The movement of capital itself is alienated. Therefore, the movement of capital inevitably leads to the alienation of the entire society. From labor alienation to the alienation of science and technology, from economic alienation to political, cultural and ideological alienation and so on, the capitalist society is an alienated society; the second is the principle of moral criticism, or the principle of cultural criticism. The basic content of this principle is to use the realization of human individual freedom as the moral standards of historical progress and the civilized-barbaric dialectics as the model to evaluate the historical significance of capitalism. In Marx's opinion, there are two dimensions to evaluate the progress of human history: one is the rational dimension based on the mode of production, and the other is the moral dimension based on the individual liberation and the free and comprehensive development of man. These two dimensions are inseparable. Revolution of the mode of production and the progress of human rationality will bring about individual liberation and promote comprehensive and free development of mankind. As a moral measure, the individual liberation and comprehensive and free

8 For detailed exposition on this issue, refer to my paper "Rational Structure of Marx's Historical Dialectics", in Journal of Nanjing University, Humanities and Social Science, 2012 (3); also "The Cultural Philosophical Quality of Marx’s Practical Materialism”, in Seeking Truth, 2007 (3).

9 Marx and Engels' Collected Works, Vol. 5, People’s Publishing House, 2009, p. 8. 
development dominate the progress of human rationality. Any reason that deviates from this dimension requires criticism. Capitalist society is the case. The capitalist society has created large industries and liberated individuals from the natural connection of the primitive community, transforming into individuals of society and the rational person, which greatly promote the progress of rationality. From this point of view, capitalism is a civilization, yet previous societies are barbaric. However, capitalist society regards the production of capital as the principle of society, which reverses the relationship between man and things, and leads to the alienation of production, labor to human nature. It is also immoral and uncivilized. The only way to eradicate this immorality and uncivilization is to realize the transformation of the social system into the communist society. From this perspective, capitalist society is barbaric, and only communist society is civilized. These two critical principles have profoundly revealed the essence of capitalist society, and thus have become the basic method for people to observe and understand capitalist society. As long as capitalism exists, this method will not be obsolete.

But, from the 19th century to the 20th century, capitalism experienced a transition from liberal capitalism to monopoly capitalism, that is to say, capitalism itself is developing. This transformation provides two different social prototypes for people to study capitalism: one is the industrial society with the large machine production, and the other is the post-industrial society with the cultural industry. It is also called the late capitalist society. These two kinds of social prototypes show people different prospects of capitalism: Industrial society displays a scientific and rational society. In this society, the capitalist mode of production is developing rapidly, destroying the feudal mode of production. The civil society's rise has separated people from the traditional natural bonds and turned them into independent individuals, and the post-industrial society shows a society of totalitarianism and popular culture. In this society, culture has saturated capital and become barbaric. The individual is suppressed by totalitarianism and loses their own value. Faced with these two different social scenes, thinkers of the 19th century and 20th century have taken an entirely different attitude towards capitalism: in the 19th century thinkers saw the power of rationality of enlightenment from the large machine production. As a result, they firmly believed in the spirit of enlightenment and adopted a positivist scientific attitude toward capitalism. Thinkers in the 20th century saw from the cultural industry the alienation of culture and the overall social alienation it brings. It is seen as deceit and lies. Therefore, they started to doubt and negate the spirit of enlightenment and adopted a critical attitude towards capitalism. Accordingly, the critical theory of the Frankfurt School developed from it.

Comparing these two social prototypes of capitalist society and the two different attitudes towards capitalism that we have developed can make us more clearly see the relationship between Adorno and Marx's critical historical philosophy. Since the construction of Marx's critical historical philosophy, Philosophy of History has had two different ways of studying social prototypes. One is to conduct empirical scientific research on a certain social prototype, and the other is to carry out critical, negative research on certain social prototype; The former can only achieve the phenomenal description of social prototype and its theory is easily understood and accepted by contemporaries, but it becomes obsolete with the disappearance of the social prototypes studied. The latter is the perspective of the nature of social prototypes and the prediction of the future of the social prototype, its theory may not be understood and accepted by people of the same age, but it will be understood and accepted by later people along with the transfer of social prototypes. This is true of Marx's critical historical philosophy. Since Marx lived in the 19th century, liberal capitalism was the social prototype of his study. However, Marx viewed liberal capitalism with a critical and negative attitude. In his opinion, large machine production brought capital, wealth to the capitalists, what brought to workers is extreme poverty, the alienation of labor and the devaluation of human life. Consequently, he starts from the analysis of the phenomenon of political economy, carries out a critique of capital, and then discusses in depth the negation of the negation of human life value, and regards the return of human life and the self-realization of human individual value as the criterion of human liberation and freedom. This introduces the critique of capital into the critique of culture and regards cultural critique as the supreme concept of critical historical philosophy. In the 19th century, the value of this idea of Marx was not recognized by people. At that time, people only understood Marx's principle of capital criticism from the perspective of political economy criticism and attributed Marx's principle of capital criticism to the study of political economy. Until the 20th century, people realized the true meaning of Marx's critical principle of capital in the general alienation of post-industrial society, and then expounded Marx's principle of capital criticism from the perspective of cultural criticism.

\section{Critique of Cultural Industry}

Adorno's critique of the cultural industry is a typical case in 20th's cultural criticism.[26][36][40][42]

In the critique of the cultural industry, Adorno first pointed out the essence of the capitalization of the cultural industry. He emphasized that the so-called cultural industry is to turn culture into industrial production and become a sector in the economy, subjecting it to the need for capital accumulation. Therefore, economic benefit, that is, maximizing the acquisition of currency, becomes the 
inherent power and direct purpose of cultural development, which will inevitably lead to a complete alienation of culture from content to form. Furthermore, he reflected the spirit of enlightenment, emphasizing that the essence of the enlightening spirit was deceit and lies, and it was through deception and lies that the cultural industry stepped out of its place of production and had an impact on people's leisure, entertainment, consumption, and the entire way of life. He pointed out: "In today's material production, when the supply and demand mechanism is destroyed, the mechanism plays a role in helping the ruler in the superstructure as a means of control. Consumers are workers and employees, farm owners and small assets. The production of capitalism is controlled tightly by the spirit and flesh, so that they are content to enjoy what it has provided for them. Of course, just as the ruled are always more serious than the ruler itself, they insist that they be from the ruler. The morals learned there, today's deceived people are more obsessed with fabulous achievements than those who have achieved fruitful results, they have aspirations, and they firmly believe in the ideology that the rulers use to enslave them. Everything given to them, enthusiastically accepting the tricks the authorities have imposed on them. ${ }^{10}[6]$ [7] [20] This fact proves that the cultural industry is based on deceit and lies which are the moral foundations of the cultural industry. It is precisely on this moral basis that the cultural industry has constructed a false cultural world. Therefore, the moral criticism of the cultural industry is the revealing of the cultural roots of the capitalization of the cultural industry.

It is not difficult to see that Adorno's critical theory is consistent with Marx's critical historical philosophy on the critical academic path through Adorno's critique of the capitalization of the cultural industry. Assuredly, we can discover the differences in their theory from the social prototype of the study and the specific content of criticism. However, these differences cannot overthrow Marx's critical historical philosophical tradition. On the contrary, it is in these differences that Marx's critical historical philosophy is recognized and understood, and is given a new interpretation. From this point of view, the difference between Adorno's critical theory and Marx's critical historical philosophy seems to be very significant.

\section{Reflections on Auschwitz}

Compared with the principle of Marx's moral critique in the form of capital critique in the criticism of the cultural industry, Adorno's expounds the principle of Marx's moral critique in an open and direct form when he reflects on Auschwitz. In reflecting on the various non-humanistic

10 Horchheimer, Adorno, Dialectics of Enlightenmnet, Translated by Hong Peiyu and Lin Yuefeng, Chongqing Publishing House, 1990, pp. 124-125. phenomena that occurred in the Auschwitz Concentration Camp, Adorno's philosophy presents a profound philosophical question: 'Can on live after Auschwitz?' This issue is a search for the value of human life, and is also a condemnation of the barbaric practices of imperialism, even more a reflection on the history of human civilization. [18][23][39] Adorno uses the principles of moral criticism of Marx's critical historical philosophy, criticizes the enlightenment spirit with a mode of civilized and barbaric dialectics, and develops Marx's critical historical philosophy on the micro level in studying this issue.

In fact, as early as Rosa Luxemburg, revealing the non-humanistic nature of imperialism and pointing out the prospect of human history in Marx's civilized and barbaric dialectics model begun. In late July 1914, the First World War broke out. On August 4, 1914, representatives of the Social Democratic Party voted in favor of war funding under the myth of defensive warfare created by the German imperialists. After this appalling incident occurred, Rosa Luxemburg wrote the famous Julius booklet, The Crisis of the Social Democratic Party, and revealed the myth of defensive war of Germany and the nature of the imperialist war. She said: 'Friedrich Engels one time said that bourgeois society is faced with a dilemma: it is either a transition to socialism or a retrogression to a barbaric state.... This world war is a retrogression to a barbaric state. The victory of imperialism will lead to the destruction of civilization.... Therefore, just as Friedrich Engels foresaw 40 years ago that the choices with which we face today are: or the victory of imperialism and destruction of all civilizations. As in ancient Rome, sparsely populated, deserted land, degraded race, a large cemetery; or the victory of socialism, that is, the realization of the struggle of the international proletariat against imperialism and its methods, namely, the realization of war. This is the dilemma of world history. It is either one or the other. The balance is swinging up and down. It is determined by the class-conscious proletariat. The future of civilization and mankind depends on whether the proletariat has strong resolution to put the sword of revolutionary struggle on the scales. In this war the imperialists won. It slaughtered people with bloody swords. The brutality prevailed, and the balance favored the abyss of suffering and shame. Only when we learned how to bring the proletariat up from the role of a servant in the hands of the ruling class to the owner of its own destiny in war and through wars, could we counteract all sufferings and shame. ${ }^{11}[48]$ This is the issue of socialism or barbarism proposed by Rosa Luxemburg. This idea of Rosa Luxemburg creates the German Marxist critical philosophy tradition.

Adorno inherited the tradition of Rosa Luxemburg's critical philosophy and also condemned Fascism's acts of devastating humanity in Marx's moral principles. In

11 Li Zongyu, ed. Selected Writings of Rosa Luxemburg, People's Publishing House, 2012, p.323. 
Adorno's view, the essence of culture is the dignity of human beings and the individual's value. However, all this is destroyed in the Auschwitz Concentration Camp. In the Auschwitz Concentration Camp, the victims are not humans, but victims of the experiments carried out by the perpetrators. That this undoubtedly trampled on the individual's personality and human values, is brutal, and is a regression of human civilization. Adorno emphasized that the phenomenon that happened in the Auschwitz Concentration Camp was in no way isolated, but that existed universally in the Second World War. For example, the United States used the atomic bomb. As it is the case that it considered human beings to be victims of experiment. That being the case, then, the condemnation of the brutality that took place in the Auschwitz Concentration Camp was not merely a critique of German fascism, but also a criticism of the nature of imperialism and a reflection on the future of human civilization. In thinking about this issue, he did not criticize the brutality of imperialism at the level of the macro-historical revolution like Rosa Luxemburg, resorted the eradication of barbarism to the proletariat, and expected the socialist revolution and the establishment of a socialist democratic system. But he exposed the brutality of imperialism from the microcosmic level of human nature, and explored the cultural roots of imperialist barbarism in the spirit of enlightenment. He pointed out that "all of these phenomena have been more or less linked to the old dictatorship, almost associate with the kind of behavioral pattern that fuels the old dictatorial character," ${ }^{12}$ [3] which occurred in the Auschwitz Concentration Camp. Therefore, to make the non-humanitarian behavior of the Auschwitz Concentration Camp no longer occur, it is necessary to reflect on the spirit of enlightenment and thoroughly change the mode of thinking and behavior since the Enlightenment. In this way, Adorno turned Rosa Luxemburg's socialism or barbarism into a cultural or barbaric issue.

Then, how does the Auschwitz Concentration Camp phenomenon relate to the spirit of enlightenment? What are the drawbacks of model of the Enlightenment? Adorno had a critical reflection on the inner structure of the Enlightenment in the concept of Enlightenment co-authored with Horkheimer and Odysseus or Myth and Enlightenment authored by himself. Adorno believes that there is a profound internal contradictions in the spirit of enlightenment: enlightenment, on the one hand, is to get rid of myths and establish an autonomous spirit. On the other hand, the basis for the establishment of an independent spirit in enlightenment is rational unity. In order to obtain a unified rationality, The Enlightenment entangled the enlightening and mythical elements that are mutually

12 Theodor W. Adorno: Can One Live after Auschwitz? A Philosophical Reader, edited by Rolf Tiedemann, Translated by Rodney Livingstone and Others, Stanford University Press 2003, P25. antagonistic with the help of myths: "Since the myth has been enlightened, the spirit of enlightenment has progressed more and they are more deeply intertwined with mythology along with the progress of mythology."13 [20] Therefore, enlightenment and mythology constitute the inherent contradiction of the Enlightenment. In this contradiction, myth has played a huge role. The myth transforms the unity of rationality into ideology and becomes the "power" of "life-immortal" nihilism, "This ideology is the same practice of blindly praising blind life and suppressing all living things." ${ }^{14}[20]$ Because of this role of the myth, elements of deception are injected into the Enlightenment, and the phenomenon of the Auschwitz Concentration Camp was generated from this essence of the enlightenment spirit. Of course, this has gone through a historical process. In the early stage of capitalism, that is, "in the early stage of the sacredness that the old bourgeois humanism was still considered to be legal, the role of neo-romanticism is consistent with interests of the bourgeoisie, and world history and enlightenment are still united. Therefore, to actively eliminate the popular ideology of the Enlightenment spirit, false hearts and minds expressly respect the spirit of enlightenment. ${ }^{15}[20]$ The spirit of enlightenment was also recognized as rational, reasonable, historical phenomenon. However, after entering the late capitalist society, the situation is different. Here, the deceptive elements of the spirit of enlightenment "have reached the peak through fascist fraud, and fascism has in turn attributed this to the spirit of enlightenment." ${ }^{16}[20]$ The fraud of Fascist is realized. Therefore through spreading and controling of ideology, ideology and cultural media have become two important tools for fascism to implement fraud.

From this Adorno's critique, we can see the complex relationship between Adorno's critical theory and Marx's critical philosophy of history. On the one hand, Adorno inherited Marx's cultural criticism which considered the realization of human life value as a measure of historical progress when he applied Marx's critical principles of morality. He raised the question:' can people still be alive after Auschwitz?' This issue is not a question about the physical existence of human beings, but a question about human dignity. This question is consistent with Marx's questions on human "life-like life" and "life-producing life" ${ }^{17}$ [2]. They are all reflections on human cultural existence and also use brutality to highlight culture and clarify the connotation of progress of human history. On the other hand, Adorno's and Marx's views differ in how to

13 Horchheimer, Adorno, Dialectics of Enlightenmnet, Translated by Hong Peiyu and Lin Yuefeng, Chongqing Publishing House, 1990, p. 9. 14 Horchheimer, Adorno, Dialectics of Enlightenmnet, Translated by Hong Peiyu and Lin Yuefeng, Chongqing Publishing House, 1990, p. 39. 15 Horchheimer, Adorno, Dialectics of Enlightenmnet, Translated by Hong Peiyu and Lin Yuefeng, Chongqing Publishing House, 1990, p. 40. 16 Horchheimer, Adorno, Dialectics of Enlightenmnet, Translated by Hong Peiyu and Lin Yuefeng, Chongqing Publishing House, 1990, p. 40. 17 Complete Works of Marx and Engels, Vol. 3, $2^{\text {nd }}$ edition, p. 273. 
eliminate barbarism. Starting from the revolutionary significance of capitalist mode of production and labor, Marx affirmed the spirit of enlightenment and believed in the rational forces of enlightenment, and used rationality of enlightenment to criticize the irrational phenomena in pre-capitalist and capitalist societies, and to make such critical power resort to the proletariat, considering the proletarian revolution as a means to eliminate barbarism, and communism as the real realization of humanitarianism. This idea of Marx was developed in Rosa Luxemburg and but in Adorno, it was interrupted. Adorno, starting from the repression of individualism and mass culture in the late capitalist system, was critical of the spirit of enlightenment and sought to expose the deceitful and false nature of the Enlightenment spirit through cultural ideological criticism, in order to eliminates the brutality of imperialism and make the Auschwitz no longer happen. Here, he resorts to the forces of eliminating barbarism to intellectuals with conscience, not to the proletariat. Because Adorno could not see the strength and progress of the proletariat, he could not also see the prospect of human social progress and thus fell into pessimism.

In spite of this, Adorno proposed a meaningful philosophical topic in his reflection on Auschwitz. This is the critique of modernity that focuses on the spirit of enlightenment. It is the study of this topic that makes Adorno move towards the construction of cultural metaphysics.

\section{Negation and Cultural Metaphysics}

In Adorno's view, the criticism of the cultural industry and the reflections on the spirit of enlightenment are only social criticism and have not yet reached the height of philosophical criticism, because these critiques only reveal the imaginary and deceptive nature of the cultural ideology. [11] Without elucidating the essence of culture, let alone, the cultural criticism has been promoted as people's conscious consciousness, making it a critical force and be a critical spirit. Therefore, it cannot be called a philosophical criticism. The task of philosophical criticism is to establish cultural metaphysics through the denial of social criticism. In the lecture of Negative Consciousness, he distinguishes between the metaphysical and metaphysical meanings of negation and clarifies the relationship between social criticism and philosophical criticism. [15] [17] [18] [19] [25] He pointed out: "The possibility of any change depends on the ability to be the ultimate negation, that is, the kind of negation at the basic level, rather than just a negation at the phenomenon level that is transient and volatile." ${ }^{18}$ [3] Adorno's negation

18 Theodor W. Adorno: Can One Live after Auschwitz? A Philosophical Reader, edited by Rolf Tiedemann, Translated by Rodney Livingstone and Others, Stanford University Press 2003, P450. here refers to criticism; what he calls "negation at the basic level" refers to the metaphysical critique, that is, the critique of philosophy; what he said "is in a transient change the superficial negation on the phenomenological level refers to the critique in the metaphysical sense, that is, the social critique. He believes that social criticism provides a critical object for philosophical critique, and that philosophical critique is to obtain cultural essence and establish a conscious awareness of culture through the denial of social critique. It can be seen that the establishment of cultural metaphysics through negation is the ultimate goal of critical theory. In contrast, criticism of the cultural industry and reflections on the spirit of enlightenment are only critical aspects of the realization of the ultimate goal of the theory. So, how is it possible to negation as cultural metaphysics? How does culture become a philosophical consciousness? The core of this issue is how to understand and define the concept of negation. For this question, Adorno inherits Marx's critical historical philosophical tradition and clarifies the negative philosophical connotation from the relationship between absolute consciousness and historical texts.

That I mention that Adorno here inherits Marx's critical historical philosophical tradition refers to identity between Adorno's negational concept and Marx's concept of negation in the philosophical spirit. Marx expounded the metaphysical significance of negation in his doctoral dissertation and Manuscript of Economics and Philosophy in 1844. In the doctoral dissertation, Marx analyzed the atomic declination theory of Epicurean, especially the analysis of the concept of repulsion in it, and emphasized that negation is the link of individual self-realization, and it is also the inner power of spiritual individual into the phenomenal world. What it expresses is the critical and mutual negative relationship between philosophy and reality, theory and practice. In this negation, the individual spirit is not detached from the phenomenal world and becomes an abstract absolute consciousness. Instead, it regards the phenomenal world as material. The medium to present the individual's free nature; In the Economic and Philosophical Manuscripts of 1844, Marx further examined negation under the condition of capitalist private ownership, stating that the individuality of society, that is, individual freedom, can be achieved only by negating dissimilated labor under conditions of capitalism. ${ }^{19}$ [49] To sum up, Marx's these expositions expound the two principles of negation of metaphysics: First, adhere to the tangles between self-consciousness and the phenomenal world; second, emphasize individual freedom and its realization. Of these two principles, the former principle is more important because it is precisely this principle that shows the fundamental difference

19 For detailed exposition on this issue, refer to He Ping, A Course on the History of Marxist Philosophy (Vol.1), People's Publishing House, 2009, pp. 44-50, 61-74. 
between Marx's critical historical philosophy and other philosophy. Adorno's elucidation of the negative meaning and the construction of the metaphysics of culture are also based on the principle of argumentation.

Adorno believes that from the perspective of cultural philosophy, the tangling between the self-consciousness and the phenomenal world is about the relationship between absolute consciousness and historical texts, that is, the relationship between absolute consciousness and cultural status. This problem can be summed up as follows: "Absolute consciousness is measured in the "state of culture", that is, "according to the consciousness of a historical and cultural situation to solve the so-called metaphysical problem." This is the "usually called intertwinement between the cultural thing and the metaphysical problem." ${ }^{20}$ [3] In this tangling, on the one hand, absolute consciousness depends on certain cultural conditions, and it is always necessary to express oneself through a certain cultural situation. On the other hand, absolute consciousness itself is not affected by certain cultural conditions, but it is based on its own negation. Sex to show the essence of culture. Adorno believes that the entanglements between cultural and metaphysical issues are exactly where historical philosophy differs from previous metaphysics. All that has been done in the past metaphysics was nothing more than the demonstration of the transcendental nature of absolute consciousness. The absolute consciousness is that consciousness has escaped the entanglements of experience and reached pure consciousness. This has made metaphysics an empty speculative philosophy. The difference is that the negativity advocated by historical philosophy is not trying to get rid of the entanglements of absolute consciousness and experience. It is precisely to argue how absolute consciousness is tangled with experience. How does absolute consciousness entangle with experience? Get the cultural nature of the rules.

When it comes to the entanglements of absolute consciousness and experience, it involves an ancient philosophical issue, namely, absolute and limited relations. Solving this problem is a breakthrough for Adorno to elucidate his negation. In solving absolute and limited relationships, Adorno analyzed Hegel's concept of mediation. Adorno pointed out that Hegel uses the concept of mediation to describe the relationship between absolute and limited, and understands intermediary as a negative activity, and abandoning limited activities. It is precisely through this negative activity that absolute consciousness is self-actualized. . With the introduction of the intermediary, Hegel broke the intuitive, mechanistic thinking and created a dialectical way of thinking. This is Hegel's philosophical contribution. However, Hegel did

20 Theodor W. Adorno: Can One Live after Auschwitz? A Philosophical Reader, edited by Rolf Tiedemann, Translated by Rodney Livingstone and Others, Stanford University Press 2003, P444. not make the dialectical way of thinking into the field of experience, because in Hegel, the intermediary is limited to the "within the extreme itself" ${ }^{21}$ [3], is subject to absolute, is absolutely self-fulfilling. The tools and links, while absolute and pure consciousness, are equivalent to religious consciousness. And it is decided that Hegel's concept of "intermediary" is merely an argumentation of theological metaphysics. It does not solve the absolute and limited tangles. Kierkegaard tried to make the agency go beyond the absolute scope and into the individual of experience. Therefore, he modified Hegel's concept of mediation, understood the agency as the idea of tending to the outside world, and understood it as an absolute connection. Limited bridges, moments of human thoughts." ${ }^{22}$ [3] Even so, Kierkegaard failed to step out of the metaphysics of theology and reach an argument for the limited, ie, individual, existence, because his argument was "an unusual and honest and rigid style used by dialectical theologians" ${ }^{23}$ [3]. To clarify the intertwinement between the culture of self-deception and the internal decline of metaphysical thoughts, the so-called theology of theology is to use a noble, perfect language to illustrate individual cultural existence. However, in the late capitalist society, the phenomena of the cultural industry and the Auschwitz concentration camp proved that the real individual is the existence of alienation, irrational, and inhuman existence, and that the noble and perfect individual cultural existence is only a kind of Fantasy, a kind of deception. In this case, Kierkegaard's use of a noble and perfect style puts his philosophy on the experience. The concept of mediation becomes an objective truth to eliminate culture, and demonstrates the absolute subject and "abstract one." "The tools that exist, and thus fall into the metaphysics of theology. Visible, Kierkegoer's intermediary concept did not solve the absolute and limited tangles. In view of the defects of the intermediary concept of Hegel and Kierkegaard, Adorno proposed the constellation mode of thinking.

Constellation ${ }^{24}$ [4]-style thinking is also an intermediary way of thinking. In this way of thinking, however, the mediation is neither self-negotiation activity of the absolute spirit understood by Hegel, nor is the abstract individual understood by Kerkegor in the dialectical theology, but is the monad in the field. It's like a constellation. The constellation is a huge force field

21 Theodor W. Adorno: Can One Live after Auschwitz? A Philosophical Reader, edited by Rolf Tiedemann, Translated by Rodney Livingstone and Others, Stanford University Press 2003, P446.

22 Theodor W. Adorno: Can One Live after Auschwitz? A Philosophical Reader, edited by Rolf Tiedemann, Translated by Rodney Livingstone and Others, Stanford University Press 2003, P446.

23 Theodor W. Adorno: Can One Live after Auschwitz? A Philosophical Reader, edited by Rolf Tiedemann, Translated by Rodney Livingstone and Others, Stanford University Press 2003, P446.

24 Theodor W. Adorno: Aesthetic Theory, Newly translated, edited, and with a translator's introduction by Robert Hullot-Kentor, published by the University of Minnesota Press, 1997, p179. 
which have numerous constellations and each of these constellations is both an existence and a gravitational field. It exists simultaneously with other constellations and compares to others by the means of its own movement to show its own personality. Adorno believes that the existence of culture is the case. The existence of culture itself is a huge constellation that is comprised of the inner field of history and metaphysical category. In this constellation, each culture constitutes a cultural constellation in accordance with its own characteristics and internal negativity. For instance, death and history constitute a constellation of life activities. Metaphysical experiences and happiness constitute a constellation of morality. Artwork and the spirit forms the aesthetic constellation, cultural criticism and cultural alienation constitute the constellation of cultural ideology, and so forth. Each of these cultural constellations consists of different individual consciousness which do not come from absolute consciousness, but come from its empirical reflection on itself and its environment. The reflection is transience of the individual's abstract experience and its abstract experience. What this abstract experience and transience of the abstract experience exist simultaneously is the silence of other individuals. The individual consciousness reflects itself and expresses its own characteristics in this field. Therefore, individuals are a monad and an individual's awareness of their own experience in the constellation. This is an absolute and limited intertwinement. Adorno's constellation-style thinking, resembles Leibniz's monad in terms of emphasizing individual self-sufficiency, but its connotation is essentially different. In Leibniz, the monad is a time sequence in which countless monads are arranged from obscure to clear, and the order of these monad is pre-established harmony by God. In Adorno, the list is a spatial orientation. This space is only a historical contingency and is a diverse and open field. In this historical field, the list is no longer the abstract individual consciousness defined by Leibniz. It is no longer the category of speculative philosophy, but an individual with a cultural nature and cultural consciousness. It is a category of historical philosophy. And with its metaphysical characteristics of culture, it has become the highest category of critical historical philosophy.

\section{Conclusions}

From the critique of the cultural industry to the building the metaphysic of culture, Adorno created his theory of criticism. According to this theory, the metaphysics of culture is the self-consciousness of culture, and yet, the self-consciousness of culture itself is negation, the power of criticism. In contrast, the cultural criticism is only the cultural form of the market in the discourse of political economy. It exists only in people's business and exchange activities, and does not enter critical reason, it therefore, is non-critical. The task of critical theory is to promote cultural criticism as a cultural concept of self-denial, self-realization, and self-transcendence through negation, that is, cultural self-consciousness. [12]

It is very important for us to understand Marx's critical historical philosophy. It allows us to see that Marx's critical historical philosophy cannot be placed in the discourse system of political economy, but must be viewed from the negative, in other words, metaphysical sense. Similarly, the principle of Marx's capital criticism and that of moral criticism cannot be applied only at the level of political economy, but should be promoted to the level of philosophical criticism. Otherwise, it will fall into vulgar cultural criticism. If we recognize Adorno's pursuit of metaphysics of culture, then it is unreasonable to exclude Adorno's philosophy from the camp of Marxist philosophy and subsume it under postmodernism.

\section{REFERENCES}

[1] Marx and Engels' Collected Works, Vol.5, People's Publishing House, 2009,

[2] Complete Works of Marx and Engels, Vol.1, 3, People's Publishing House, 2nd edition.

[3] Theodor W. Adorno: Can One Live after Auschwitz? A Philosophical Reader, edited by Rolf Tiedemann, Translated by Rodney Livingstone and Others, Stanford University Press 2003.

[4] Theodor W. Adorno: Aesthetic Theory, Newly translated, edited, and with a translator's introduction by Robert Hullot-Kentor, published by the University of Minnesota Press, 1997.

[5] Theodor W. Adorno: Against Epistemology: A Metacritique: Studies in Husserl and the Phenomenological Antinomies, trans. W. Domingo, Cambridge, Mass: MIT Press, 1982.

[6] Theodor W. Adorno: An Introduction to Dialectics (1958), edited by Christoph Zierrmann, Translated by Nicholas Walker, Polity, 2017

[7] Theodor W. Adorno: Einführung in die Dialektik (1985), Herausgegeben von Christoph Ziermann, Suhrkamp, Verlag, 2010.

[8] Theodor W. Adorno: The Authoritarian Personality, New York: Harper \& Brothers, 1950.

[9] Theodor W. Adorno: Critical Models: Interventions and Catchwords, trans. H. W. Pickford, New York: Columbia University Press. 1988.

[10] Theodor W. Adorno: Hegel: Three Studies, trans S. Weber Nicholsen, Cambridge, Mass.: MIT Press.1993.

[11] Theodor W. Adorno: Introduction to Sociology, edited by Christoph Gödde, Translated by Edumund Jephcott, California Stanford Univeristy Press, 2000.

[12] Theodor W. Adorno: History and Freedom: Lectures 
1964-1965, Edited by Rolf Tiedemann, Translated by Rodney Livingstone, Cambridge: Polity, 2006.

[13] Theodor W. Adorno: Kant’s Critique of Pure reason (1959), Edited by Rolf Tiedenmann, translated by Rodney Livingstone, Stanford: Stanford University Press, 2001.

[14] Theodor W. Adorno: Lectures on Negative Dialectics: Fragments of a Lecture course 1965/1966, Edited by Rolf Tiedemann, Translated by Rodney Livingstone, Cambridge: Polity, 2008.

[15] Theodor W. Adorno: Metaphysics: Concept and Problems (1965), Edited by Rolf Tiedemann, Translated by Edmund Jephcott, Polity, 2000.

[16] Theodor W. Adorno: Negative dialectics, tran. E.B. Ashton, New York: Seabury Press, 1973.

[17] Theodor W. Adorno: Ontology and Dialectics (1960/1961), Herausgegenben von Rolf Tiedemann, Suhrkamp, 2002.

[18] Theodor W. Adorno: Philosphy of New Music, trans. Ed, and with an introduction by R. Hullot-Kentor, Minneapolis. University of Minnesota Press, 2006.

[19] Theodor W. Adorno: Problems of Moral philosophy (1963), ed. T. schröder, trans. R. Livingstone, University Press, 2000.

[20] Horchheimer, Adorno, Dialectics of Enlightenmnet, Translated by Hong Peiyu and Lin Yuefeng, Chongqing Publishing House, 1990

[21] Max Horkheimer: The Present Situation of Social Philosophy and the Tasks of an Institute for Social Research, Max Horkheimer: Between Philosophy and Social Science, selected Early Writings, The MIT Press, Cambridge, Massachusetts, Cambridge, Massachusetts.

[22] Fredric Jameson. Late Marxism:Adorno, or, the persistence of the dialectic, Nanjing University Press,2008.

[23] Alastair Morgan: Adorno’s concept of Life, New York: continuum, 2007.

[24] Andrew Bowie, A Adorno and the Ends of Philosophy, Cambridge: Polity, 2013.

[25] Brian O’Connor Adorno's Negative Dialectic: Philosophy and the Possibility of Critical Rationality, Cambridge: MIT Press, 2004.

[26] Deborah Cook, (ed): Theodor Adorno: Key Concepts, Durham, UK: Acumen, 2008.

[27] Donald A. Burke: Adorno and the Need in Thinking: New Critical Essay, Toronto: Univeristy of Toronto Press, 2007.

[28] Eric L. Krakauer: The disposition of the subject: Reading Adorno's Dialectics of Technology, Evanston: Northwestern University Press, 1998.

[29] Fabian Freyenhagen: Adorno's Practical Philosophy: Living Less Wrongly, Cambridge: Cambridge University Press, 2013.

[30] Gerhard Schweppenhauser, Theodor W. Adorno: An Introduction, Durham: Duke University Press, 2009.

[31] Gibson N. C. and A. Robin, (eds.) Adorn: a Critical Rader, Oxford, Blackwell, 2002.

[32] Hauk Brunkhorst: Adorno and Critical Theory, Cardiff:
University of Wales Press, 1999.

[33] Javis, S: Adorno: A Critical Introduction, New York routledge, 1998.

[34] Jenemann. D: Adorno in America, Minnecapolis: University of Minnesota Press, 2007.

[35] Lunn. E: Marxism and Modernism: An Historical Study of Lukács, Brecht, Benjamin and Adorno, Berkeley: University of California Press, 1982.

[36] Robert W. witikin: Adorno on Popular Culture, Liondon and New York, Routledge, 2003.

[37] Sherman D: Sartre and Adorno: The Dialectics of Subjectivety, Albany, State University of New York Press, 2007.

[38] Sherratt, Y: Adorno"s Positive Dialectic, Cambridge: Cambridge University Press, 2002.

[39] Shuster, M: Autonomy after Auschwitz: Adorno, German Idealism and Modernity, Chicago, The University of Chicago Press, 2014.

[40] Simon Jarvis (ed). Theodor w. Adorno: Critical Evaluations in Cultural Theory, Volum 1-4, New York, Routledge, 2007.

[41] Susan Buch-Morss: The Origin of Negative Dialectics: Theodor W. adorno, walter Benjamin and the Frankfurt Institute, New York, Free press, 1977.

[42] Witkin R. W: Adorno on Popular Culture, New York, Routledge, 2003.

[43] He Ping and Wu Xinwei (ed.): Frankfurt School and America Marxism, Reople’s Publishing House, 2014.

[44] G. Vico: New Science, translated by Zhu Guangqian, People Literature Publishing House, 1986.

[45] Selections from the Prison Notebooks of Antonio Gramsci, edited and by translated by Quintin Hoare and Geoffrey Nowell Smith, Wawrence nad Wishart Press, 1971.

[46] Georg Lukács: Geschichte und Klassenbewusstsein: Studien über Marxistische Dialektik, Hemann Luchterhand Verlag GmbH \& Co. KG, Darmstadt und Neuwied, Muenchen, 1971.

[47] Herbert Marcuse: Reason and Revolution: Hegel and the Rise of Social Theory, Oxford University Press, 1941.

[48] Li Zongyu, ed. Selected Writings of Rosa Luxemburg, People’s Publishing House, 2012.

[49] He Ping: A Course on the History of Marxist Philosophy (Vol.1), People’s Publishing House, 2009.

i Subject: This paper is belonged to the autonomic subject of Wuhan University for scientific research (Humanities and Social Sciences), and supported by "the Fundamental Research Fund for the Central Universities”.

ii Author: He Ping, PhD, Professor in School of Philosophy, Wuhan University, Director of Institute of Western Marxist Philosophy, Researcher in Center of Marxist Theory and Chinese Practice Co-Innovation. 